\title{
STRATEGI SIAPA MAU KERJA APA DALAM PENGEMBANGAN MODEL QUADRUPLE HELIX SINERGITAS ANTARA PEMERINTAH, PERGURUAN TINGGI, INDUSTRI, DAN MASYARAKAT
}

\author{
Muhammad Yusuf Qamaruddin ${ }^{1}$, Sapar $^{2}$, Muh. Risal ${ }^{3}$, Rahmad Solling Hamid ${ }^{4}$ \\ Email: ${ }^{1)}$ yusufq@ stiem.ac.id, ${ }^{2)}$ sapar@ stiem.ac.id, ${ }^{3}$ )mrisal@ stiem.ac.id, \\ ${ }^{4)}$ rahmadhamid@stiem.ac.id \\ ${ }^{1,2)}$ Prodi Ilmu Ekonomi Pembangunan, Sekolah Tinggi Ilmu Ekonomi Muhammadiyah Palopo \\ ${ }^{3,4)}$ Prodi Manajemen, Sekolah Tinggi Ilmu Ekonomi Muhammadiyah Palopo
}

\begin{abstract}
Abstrak
Penelitian ini bertujuan untuk mengidentifikasi faktor apa saja yang menjadi kekuatan, kelemahan, peluang, dan ancaman bagi SDM tenaga kerja di Kota Palopo serta menganalisis model strategi siapa mau kerja apa yang efektif bagi SDM tenaga kerja di Kota Palopo. Jumlah populasi yang akan digunakan pada penelitian ini direncanakan sebanyak 529 orang dan untuk penggunaan sampel diambil sebanyak 88 orang dengan menggunakan rumus slovin dan diambil secara proporsional. Metode analisis yang digunakan yaitu analisis SWOT (Strength, Weakness, Opportunity, dan Threat). Berdasarkan hasil analisis untuk uji validitas dan reliabilitas kedua duanya memenuhi syarat dimana untuk uji validitas keseluruhan dari butir pernyataat didalam kuesioner memiliki nilai sig $<0,05$ sedangkan untuk uji reliabilitas dihasilkan nilai alpha hitung > 0,60. Dari hasil perhitungan matrik IFAS dan EFAS dihasilkan posisi kuadran yaitu pada posisi Kuadran I artinya rekomendasi strategi yang diberikan adalah Progresif, artinya organisasi dalam kondisi prima dan mantap sehingga sangat dimungkinkan untuk terus melakukan ekspansi, memperbesar pertumbuhan dan meraih kemajuan secara maksimal. Selanjutnya dihasilkan dua belas strategi yaitu masingmasing strategi S-O tiga rumusan strategi; Strategi S-T dua rumusan strategi; Strategi W-O lima rumusan strategi; Strategi W-T dua rumusan strategi.
\end{abstract}

Kata Kunci: SWOT, SDM Tenaga Kerja, dan Quadruple Helix

\section{PENDAHULUAN}

\section{A. Latar Belakang}

Luas wilayah administrasi Kota Palopo 247,52 $\mathrm{Km}^{2}$. Secara administratif Kota Palopo dengan 9 (sembilan) wilayah administrasi kecamatan yang meliputi Kecamatan Wara, Kecamatan Wara Utara, Kecamatan Wara Selatan, Kecamatan Wara Timur, Kecamatan Wara Barat, Kecamatan Sendana, Kecamatan Mungkajang, Kecamatan Bara dan Kecamatan Telluwanua dengan jumlah 48 kelurahan. Sebagian besar wilayah Kota Palopo merupakan dataran rendah, sesuai dengan keberadaannya sebagai daerah yang terletak di pesisir pantai. Jarak seluruh ibukota kecamatan ke ibukota Kota Palopo semua relatif dekat, berkisar antara 1 - $5 \mathrm{~km}$, yang terjauh adalah ibukota Kecamatan Telluwanua dengan jarak tercatat sekitar 12,00 km.

Posisi Kota Palopo secara geografis terletak antara 2053'15" - 3004'08" Lintang Selatan dan 120 03'10" $120^{\circ} 14$ '34" Bujur Timur. Adapunbatasan wilayah administrasi Kota Palopo terdiri dari : (1) Sebelah Utara berbatasan dengan Kabupaten Luwu; (2) Sebelah Timur berbatasan dengan Teluk Bone; (3) Sebelah Selatan berbatasan dengan Kabupaten Luwu; dan (3) Sebelah Barat berbatasan dengan Kabupaten Toraja Utara. Dimana jumlah penduduk yang ada di Kota Palopo dalam kurun waktu 3 tahun terakhir cenderung mengalami peningkatan yaitu masing-masing untuk tahun 2015 sebesar 168.894 jiwa, tahun 2016 sebesar 172.916 jiwa, dan tahun 2017 sebesar 176.907 jiwa (BPS Kota Palopo dalam Angka 2017). 
Tabel 1.1 Jumlah Pencari Kerja Terdaftar Menurut Tingkat Pendidikan Tertinggi yang Ditamatkan dan Jenis Kelamin di Kota Palopo, 2016

\begin{tabular}{lccc}
\hline \multirow{2}{*}{ Pendidikan Tertinggi yang Ditamatkan } & \multicolumn{3}{c}{ Jenis Kelamin } \\
\cline { 2 - 4 } & Laki-laki & Perempuan & Jumlah \\
\hline Tidak/Belum Pernah Sekolah & - & - & - \\
Tidak/Belum Tamat SD & - & - & - \\
Sekolah Dasar & 4 & - & 4 \\
Sekolah Menengah Pertama & 4 & 2 & 6 \\
Sekolah Menengah Atas & 274 & 173 & 447 \\
Sekolah Menengah Atas Kejuruan & 296 & 93 & 389 \\
Diploma I/II/III/Akademi & 100 & 72 & 172 \\
Universitas & 129 & 122 & 251 \\
\hline Jumlah/Total & $\mathbf{8 0 7}$ & $\mathbf{4 6 2}$ & $\mathbf{1 . 2 6 9}$ \\
\hline
\end{tabular}

Sumber: BPS Kota Palopo Dalam Angka 2017

Berdasarkan data yang dihimpun oleh BPS Kota Palopo dalam angka 2017 yang disajikan pada tabel 1.1 diatas terlihat bahwa jumlah pencari kerja terdaftar menurut tingkat pendidikan tertinggi yang ditamatkan dan jenis kelamin diakhir tahun 2016 yaitu berjumlah 1.269 jiwa. Jumlah ini masih didominasi tingkat pendidikan sekolah menengah pertama dan sekolah menengah kejuruan yaitu masing-masing 447 jiwa dan 389 jiwa, disusul tingkat pendidikan dari universitas dan Diploma I/II/III/Akademi yaitu masing-masing 251 jiwa dan 172 jiwa, dan yang paling rendah yaitu dari kalangan tingkat pendidikan sekolah dasar dan sekolah menengah pertama yaitu dengan jumlah angka yang sama yaitu 4 jiwa. Hal ini tentunya memberikan informasi bahwa masyarakat Kota Palopo yang mencari pekerjaan masih sangat membutuhkan lapangan pekerjaan.

Berdasarkan data yang dihimpun pada Rencana Pembangunan Jangka Menengah Daerah Kota Palopo 2013-2018 (2013) bahwa secara umum, perkembangan perekonomian Kota Palopo dari tahun ke tahun semakin meningkat. Namun di sisi lain ada beberapa isu dalam aspek kesejahteraan rakyat antara lain (1) ketimpangan distribusi pendapatan antar wilayah kecamatan; (2) pendapatan perkapita masih dibawah rata-rata nasional;

(3) rendahnya kontribusi Pendapatan Asli Daerah; (4) kualitas pendidikan yang masih rendah; (5) rendahnya jumlah penduduk yang memiliki sertifikat hak milik atas tanah; (6) masih kurangnya lapangan pekerjaan; (7) masih tingginya angka kriminalitas; dan (8) bidang budaya seni dan olah raga.

Isu strategis tentang pembangunan nasional dan daerah Kota Palopo erat kaitannya dengan Peraturan Presiden Nomor 32 Tahun 2011 Tentang MasterplanPercepatan dan Perluasan Pembangunan Ekonomi Indonesia 2011-2025, yaitu menepatkan SDM sebagai salah satu elemen untuk mencapai strategi pelaksanaan MP3EI yakni dengan memperkuat kemampuan SDM dan iptek nasional dalam mendukung pengembangan program utama disetiap koridor eknomi. Untuk menjawab tantangan ini tentunya dibutuhkan model kerjasama yang bersifat kontinuitas dan bersinergi. The Quadruple Helix telah memberikan metafora yang dapat digunakan dalam pemodelan ekonomi berbasis pengetahuan dan inovasi.

Dengan demikian berdasarkan data dan informasi yang telah diuraikan diatas maka pemerintah Kota Palopo dan Sekolah Tinggi Ilmu Ekonomi Muhammadiyah Palopo melakukan kerjasama dalam kegiatan penelitian yaitu Strategi Siapa Mau Kerja Apa Dalam Pengembangan Model Quadruple Helix Sinergitas Antara Pemerintah, Perguruan Tinggi, Industri dan Masyarakat.

\section{B. Rumusan Masalah}

Berdasarkan pada uraian latar belakang diatas maka yang mencadi fokus rumusan masalah yaitu:

1. Faktor apa saja yang menjadi kekuatan, kelemahan, peluang, dan ancaman bagi SDM tenaga kerja di Kota Palopo?

2. Bagaimanakah merumuskan model strategi peningkatan SDM tenaga kerja di Kota Palopo?

\section{Tujuan Penelitian}

1. Mengidentifikasi faktor apa saja yang menjadi kekuatan, kelemahan, peluang, dan ancaman bagi SDM tenaga kerja di Kota Palopo

2. Mengkaji rumusan model strategi yang efektif bagi SDM tenaga kerja di Kota Palopo.

\section{TINJAUAN PUSTAKA}

\section{A. Ketenagakerjaan}

Salah satu indikator penting dalam mendukung pembangunan ekonomi yaitu ketenagakerjaan. Isu terkait tentang masalah kesempatan kerja dan pertumbuhan ekonomi baik dalam skla nasional maupun regional mendapat perhatian banyak orang. Pertumbuhan ekonomi yang tinggi membutuhkan penambahan investasi dan kebijakan ekonomi yang kondusif merupakan hal penting. (Muhdar, 2015).

Dalam istilah Badan Pusat Statistik (2007), beberapa istilah ketenagakerjaan yang mesti dipahami sebagai 
dasar dalam memahami masalah tersebut di Indonesia di antaranya (1) tingkat partisipasi angkatan kerja yang merupakan indikator yang dapat menggambarkan keadaan penduduk yang berumur 15 tahun ke atas yang berpartisipasi dalam kegiatan ekonomi, (2)tingkat pengangguran terbuka, dan (3) penyerapan tenaga kerja yaitu merekayang terserap diberbagai lapangan pekerjaan pada suatu periode.

\section{B. Defenisi Pengangguran dan Jenis-Jenis Pengangguran}

Pengangguran adalah seseorang yang tergolong angkatan kerja dan ingin mendapat pekerjaan tetapi belum dapat memperolehnya. (Muhdar, 2015). Pengangguran sering diartikan sebagai angkatan kerja yang belum bekerja atau tidak bekerja secara optimal.

Berdasarkan pengertian diatas, maka pengangguran dapat dibedakan menjadi tiga macam yaitu (Muhdar, 2015):

1. Pengangguran Terselubung (Disguissed Unemployment) adalah tenaga kerja yang tidak bekerja secara optimal karena suatu alasan tertentu;

2. Setengah Menganggur (Under Unemployment) adalah tenaga kerja yang tidak bekerja secara optimal karena tidak ada lapangan pekerjaan, biasanya tenaga kerja setengah menganggur ini merupakan tenaga kerja yang bekerja kurang dari 35 jam selama seminggu;

3. Pengangguran Terbuka (Open Unemployment) adalah tenaga kerja yang sungguh-sungguh tidak mempunyai pekerjaan. Pengganguran jenis ini cukup banyak karena memang belum mendapat pekerjaan padahal telah berusaha secara maksimal.

\section{Faktor-faktor Penyebab Terjadinya Pengangguran}

Faktor-faktor yang menyebabkan terjadinya pengganguran adalah sebagai berikut (Muhdar, 2015):

1. Besarnya Angkatan Kerja Tidak Seimbang dengan Kesempatan Kerja. Ketidakseimbangan terjadi apabila jumlah angkatan kerja lebih besar daripada kesempatan kerja yang tersedia. Kondisi sebaliknya sangat jarang terjadi.

2. Struktur Lapangan Kerja Tidak Seimbang.

3. Kebutuhan jumlah dan jenis tenaga terdidik dan penyediaan tenaga terdidik tidak seimbang. Apabila kesempatan kerja jumlahnya sama atau lebih besar daripada angkatan kerja, pengangguran belum tentu tidak terjadi. Alasannya, belum tentu terjadi kesesuaian antara tingkat pendidikan yang dibutuhkan dan yang tersedia. Ketidakseimbangan tersebut mengakibatkan sebagian tenaga kerja yang ada tidak dapat mengisi kesempatan kerja yang tersedia.
4. Meningkatnya peranan dan aspirasi Angkatan Kerja Wanita dalam seluruh struktur Angkatan Kerja Indonesia.

5. Penyediaan dan Pemanfaatan Tenaga Kerja antar daerah tidak seimbang. Jumlah angkatan kerja disuatu daerah mungkin saja lebih besar dari kesempatan kerja, sedangkan di daerah lainnya dapat terjadi keadaan sebaliknya. Keadaan tersebut dapat mengakibatkan perpindahan tenaga kerja dari suatu daerah ke daerah lain, bahkan dari suatu negara ke negara lainnya.

\section{Dampak Pengangguran Terhadap Perekonomian}

Untuk mengetahui dampak pengganguran terhadap perekonomian kita perlu mengelompokkan pengaruh pengganguran terhadap dua aspek ekonomi, yaitu (Muhdar, 2015):

1. Dampak pengangguran terhadap perekonomian suatunegara.

Tujuan akhir pembangunan ekonomi suatu negara pada dasarnya adalah meningkatkan kemakmuran masyarakat dan pertumbuhan ekonomi agar stabil dan dalam keadaan naik terus. Jika tingkat pengangguran di suatu negara relatif tinggi, hal tersebut akan menghambat pencapaian tujuan pembangunan ekonomi yang telah dicita-citakan. Hal ini terjadi karena pengganguran berdampak negatif terhadap kegiatan perekonomian, seperti yang dijelaskan di bawah ini:

a. Pengangguran bisa menyebabkan masyarakat tidak dapat memaksimalkan tingkat kemakmuran yang dicapainya. Hal ini terjadi karena pengangguran bisa menyebabkan pendapatan nasional riil (nyata) yang dicapai masyarakat akan lebih rendah daripada pendapatan potensial (pendapatan yang seharusnya). Oleh karena itu, kemakmuran yang dicapai oleh masyarakat pun akan lebih rendah.

b. Pengangguran akan menyebabkan pendapatan nasional yang berasal dari sektor pajak berkurang. Hal ini terjadi karena pengangguran yang tinggi akan menyebabkan kegiatan perekonomian menurun sehingga pendapatan masyarakat pun akan menurun. Dengan demikian, pajak yang harus dibayar dari masyarakat pun akan menurun. Jika penerimaan pajak menurun, dana untuk kegiatan ekonomi pemerintah juga akan berkurang sehingga kegiatan pembangunan pun akan terus menurun.

c. Pengangguran tidak menggalakkan pertumbuhan ekonomi. Adanya pengangguran akan menyebabkan daya beli masyarakat akan berkurang sehingga permintaan terhadap barang-barang hasil produksi akan berkurang. Keadaan demikian tidak merangsang kalangan Investor (pengusaha) untuk melakukan perluasan atau pendirian industri baru. Dengan 
demikian tingkat investasi menurun sehingga pertumbuhan ekonomipun tidak akan terpacu.

2. Dampak pengangguran terhadap individu yang mengalaminya dan masyarakat. Berikut ini merupakan dampak negatif pengangguran terhadap individu yang mengalaminya dan terhadap masyarakat pada umumnya:

a. Pengangguran dapat menghilangkan mata pencaharian;

b. Pengangguran dapat menghilangkan ketrampilan;

c. Pengangguran akan menimbulkan ketidakstabilan sosial politik.

Menurut Leydesdorff dan Meyer (2013), model triple helix merupakan satu dari bentuk sistem inovasi yang berbasiskan pengetahuan (knowledge-based innovation system) yang mencoba menangkap dinamika komunikasi maupun organisasi dengan mengenalkan gagasan suatu hamparan pertukaran relasi yang bolak-balik (feed back) pada penyusunan institusi.

\section{E. Quadruple Helix}

Secara paralel, konsep quadruple helix dikembangkan dengan mempertahankaninteraksi dari triple helix model (jaringan iptek antara perguruan tinggi, industri, danpemerintah) serta melibatkan masyarakat sipil secara utuh dalam sistem (Yawson, 2009). Menurut Leydesdorff dan Meyer (2013), model triple helix merupakan satu dari bentuk sistem inovasi yang berbasiskan pengetahuan (knowledge-based innovation system) yang mencoba menangkap dinamika komunikasi maupun organisasi dengan mengenalkan gagasan suatu hamparan pertukaran relasi yang bolak-balik (feed back) pada penyusunan institusi. Arnkil et al. (2010) mengusulkan beberapa jenis quadruple helix model, yang manamasing-masingmodel yang diusulkan dicirikan oleh inovasi yang spesifik dari siapa inovasi yangdimunculkan dan keterlibatan masyarakat sipil. Model yang pertama yaitu inovasi berasaldari kombinasi industri dan perguruan tinggi sebagai pengusul inovasi, dimana inovasi yangdirancang berdasarkan pada kebutuhan masyarakat sipil. Model yang kedua adalah model labhidup, dimana inovasi berpusat pada industri dan warga sipil sebagai informan danpengembang. Model ketiga adalah inovasi berpusat kepada pemerintah, inovasi dirancangdengan warga sipil dengan sistem informasi umpan balik dari warga sipil yang dapatdikumpulkan melalui survey dan wawancara. Model keempat adalah inovasi berpusat padamasyarakat sipil dengan dukungan dari tiga pihak yang lain yaitu industri, perguruan tinggi,dan pemerintah.

Penekanan quadruple helix model adalah pertumbuhan ekonomi dengan inovasi dalam penerapan sains dan teknologi memperhatikan kebutuhan warga sipil, tetapi inovasi yang dilakukan sering sekali menyebabkan terjadinya kerusakan lingkungan, oleh sebab itu para ahli mengembangkan model yang lain yaitu quintuple helix model yang memperhatikan lingkungan (Padil dan Titi, 2018).

\section{METODE PENELITIAN}

\section{A. Jenis Penelitian dan Lokasi Penelitian}

Metode penelitian yang digunakan dalam penelitian ini adalah metode deskriptif dengan melakukan kajian terhadap ketenagakerjaan di Kota Palopo. Pengolahan data pada penelitian ini dilakukan secara kualitatif dan kuantitatif.

\section{B. Jenis dan Sumber Data}

Data yang digunakan pada penelitian ini adalah data primer dan data sekunder. Data primer merupakan data yang diperoleh dari pengamatan langsung di lapangan dan data yang diperoleh dari hasil wawancara dan pengisian kuesioner oleh responden pilihan. Hal yang harus dipastikan adalah responden tersebut merupakan pihak yang memahami tentang perkembangan kondisi ketenagakerjaan di Kota Palopo. Data sekunder merupakan data pendukung dari data primer yang diperoleh dari studi literature yang terkait seperti SKPD Kota Palopo, penelitian terdahulu, dan bahan pustaka lain yan grelevan (Sugiyono, 2009).

\section{Populasi dan Sampel \\ 1. Populasi}

Jumlah populasi yang akan digunakan pada penelitian ini direncanakan sebanyak 529 orang. Adapun jumlah populasi dalam penelitian ini adalah :

Tabel 3.1 Jumlah Populasi

\begin{tabular}{|c|l|c|}
\hline No & \multicolumn{1}{|c|}{ Informan } & Jumlah \\
\hline 1 & Camat & 9 \\
\hline 2 & Ketua RW & 45 \\
\hline 3 & Pengusaha & 54 \\
\hline 4 & Tokoh Masyarakat & 36 \\
\hline 5 & $\begin{array}{l}\text { Anggota Lembaga Swadaya } \\
\text { Masyarakat }\end{array}$ & 9 \\
\hline 6 & Karyawan & 90 \\
\hline 7 & Pengangguran & 180 \\
\hline 8 & Pemilik Lembaga Pembiayaan & 18 \\
\hline 9 & $\begin{array}{l}\text { Penanggung jawab Lembaga } \\
\text { Pelatihan }\end{array}$ & 9 \\
\hline 10 & Universitas/Perguruan Tinggi & 14 \\
\hline 11 & SKPD Total & 40 \\
\hline 12 & Anggota DPRD Kota Palopo & 25 \\
\hline & \multicolumn{2}{|c|}{. } \\
\hline
\end{tabular}

Sumber: Hasil Survey Ketenagakerjaan (2016). 


\section{Sampel}

Penentuan jumlah sampel dilakukan dengan menggunakan rumus slovin, sebagai berikut:

$$
\mathrm{n}=\begin{gathered}
\mathrm{N} \\
\mathrm{N} \cdot \mathrm{d}^{2}+1
\end{gathered}
$$

$\mathrm{N}=$ Jumlah Populasi $=504$

$\mathrm{d}^{2}=$ Presisi (ditetapkan 10\% dengan tingkat kepercayaan $90 \%$ )

Berdasarkan rumus tersebut diperoleh jumlah sampel sebagai berikut:

$$
\mathrm{n}=\frac{529}{529 \cdot(0,10)^{2}+1}=87,58 \text { dibulatkan } 88
$$

Dengan rumus diatas, maka diperoleh jumlah sampel yang akan digunakan sebagai informan yaitu sebagai berikut:

Tabel 3.2 Perhitungan Jumlah Sampel Penelitian

\begin{tabular}{|c|l|c|c|}
\hline No & \multicolumn{1}{|c|}{ Informan } & \multicolumn{2}{|c|}{ Sampel } \\
\hline 1 & Camat & $9 / 529 * 88$ & 2 \\
\hline 2 & Ketua RW & $45 / 529 * 88$ & 7 \\
\hline 3 & Pengusaha & $54 / 529 * 88$ & 9 \\
\hline 4 & Tokoh Masyarakat & $36 / 529 * 88$ & 6 \\
\hline 5 & $\begin{array}{l}\text { Anggota Lembaga } \\
\text { Swadaya Masyarakat }\end{array}$ & $9 / 529 * 88$ & 1 \\
\hline 6 & Karyawan & $90 / 529 * 88$ & 15 \\
\hline 7 & Pengangguran Lembaga & $180 / 529 * 88$ & 30 \\
\hline 8 & $\begin{array}{l}\text { Pemilik } \\
\text { Pembiayaan }\end{array}$ & $9 / 529 * 88$ & 4 \\
\hline 9 & $\begin{array}{l}\text { Penanggungjawab } \\
\text { Lembaga Pelatihan }\end{array}$ & 1 \\
\hline 10 & $\begin{array}{l}\text { Universitas/Perguruan } \\
\text { Tinggi }\end{array}$ & $14 / 529 * 88$ & 3 \\
\hline 11 & SKPD Kota & $25 / 529 * 88$ & 4 \\
\hline 12 & $\begin{array}{l}\text { Anggota DPRD } \\
\text { Palopo } \quad \text { Total }\end{array}$ \\
\hline \multicolumn{3}{|c|}{88} \\
\hline
\end{tabular}

Berdasarkan perhitungan sampel pada tabel 3.2 diatas, maka dapat dilihat jumlah sampel yang mewakili dari populasi yang disajikan pada tabel 3.3 berikut yaitu:

Tabel 3.3 Jumlah Sampel Penelitian

\begin{tabular}{|c|l|c|c|}
\hline \multirow{2}{*}{ No } & \multirow{2}{*}{ Informan } & \multicolumn{2}{c|}{ Jumlah } \\
\cline { 3 - 4 } 1 & \multirow{2}{*}{ Camat } & Populasi & Sampel \\
\cline { 3 - 4 } & Ketua RW & 9 & 2 \\
\hline 3 & Pengusaha & 54 & 7 \\
\hline 4 & Tokoh Masyarakat & 36 & 6 \\
\hline
\end{tabular}

\begin{tabular}{|c|l|c|c|}
\hline 5 & $\begin{array}{l}\text { Anggota Lembaga } \\
\text { Swadaya Masyarakat }\end{array}$ & 9 & 1 \\
\hline 6 & Karyawan & 90 & 15 \\
\hline 7 & Pengangguran & 180 & 30 \\
\hline 8 & $\begin{array}{l}\text { Pemilik Lembaga } \\
\text { Pembiayaan }\end{array}$ & 18 & 4 \\
\hline 9 & $\begin{array}{l}\text { Penanggungjawab } \\
\text { Lembaga Pelatihan }\end{array}$ & 9 & 1 \\
\hline 10 & $\begin{array}{l}\text { Universitas/Perguruan } \\
\text { Tinggi }\end{array}$ & 14 & 4 \\
\hline 11 & SKPD Kota & 40 & 7 \\
\hline 12 & $\begin{array}{l}\text { Anggota DPRD } \\
\text { Palopo }\end{array}$ & $\mathbf{5 2 9}$ & $\mathbf{8 8}$ \\
\hline \multicolumn{2}{|c|}{ Total } \\
\hline
\end{tabular}

Adapun teknik pengambilan sampel yaitu dilakukan dengan menggunakan eknik purposive sampling yaitu didasarkan dengan pertimbangan tertentu sesuai dengan kebutuhan penelitian sebagai berikut: 1) Aparat pemerintah setempat setiap kecamatan; 2) Satuan Perangkat Kerja Daerah (SKPD) Kota Palopo; 3) Pimpinan, Dekan Universitas/Perguruan Tinggi lebih di fokuskan ke Fakultas Ekonomi; 4) Pengusaha baik yang memiliki ataupun berpotensi menerima karyawan; 5) Toko masyarakat yang dianggap berpengaruh dilingkungan kecamatan; 6) Karyawan yang bekerja didalam Kota Palopo; 7) Pengurus Lembaga Swadaya Masyarakat (LSM); 8) Penyedia modal; 9) Penanggungjawab lembaga pelatihan; 10) Usia responden tidak lebih dari 65 tahun bagi pengangguran; 11) Responden yang belum pernah bekerja (pengangguran); 12) Karyawan PHK; 13) Anggota DPRD Kota Palopo.

\section{Metode Analisis Data}

Adapun metode analisis yang akan digunakan dalam penelitian ini yaitu metode analisis SWOT yang terdiri dari pengambungan unsure kekuatan (Strengths), kelemahan (Weaknesses), peluang (Opportunities), dan ancaman (Threats) yang mampu menghasilkan suatu strategi yang didasarkan pada situasi lingkungan internal dan eksternal.

\section{HASIL PENELITIAN}

\section{Identifikasi Faktor-Faktor Strategis Internal Ketenagakerjaan di Kota Palopo}

Berdasarkan dari hasil penelitian berupa survey ketenagakerjaan (2016) yang telah dilakukan sebelumnya maka yang menjadi kekuatan dan kelemahan mengenai kondisi ketenagakerjaan di Kota Palopo adalah sebagai berikut :

1. Faktor-faktor yang menjadi kekuatan mengenai kondisi ketenagakerjaan di Kota Palopo:

a. Posisi geografis Kota Palopo yang strategis dalam menunjang terciptanya titik tumbuh ekonomi serta 
distribusi barang dan jasa dalam rangka pertumbuhan ekonomi Kota Palopo.

b. Ketersediaan infrastruktur sarana pendidikan, perguruan tinggi dan lembaga pelatihan dalam rangka menjamin peningkatan pengetahuan dan keterampilan kerja.

c. Ketersediaan lembaga jasa keuangan dalam rangka menjamin modal usaha.

d. Ketersediaan infrastruktur dasar seperti sarana kesehatan, irigasi, dan infrastruktur jalan dalam rangka pertumbuhan ekonomi yang lebih baik.

e. Sarana dan prasarana perekonomian seperti pasar dan kawasan ekonomi lainnya di Kota Palopo dalam rangka mencapai pertumbuhan ekonomi yang baik.

f. Ketersediaan lapangan pekerjaan dalam menyerap tenaga kerja di Kota Palopo.

2. Faktor-faktor yang menjadi kekuatan mengenai kondisi ketenagakerjaan di Kota Palopo:

a. Etos kerja, keuletan, dan jiwa kewirausahaan masyarakat disektor perekonomian mikro dalam upaya mendukung pertumbuhan makro perekonomian Kota Palopo.

b. Persaingan antara pencari kerja di Kota Palopo tidak hanya didominasi oleh masyarakat lokal tetapi juga masyarakat dari luar Kota Palopo.

c. Tingkat pendidikan dan keterampilan syarat utama yang harus dimiliki untuk bekerja pada instansi atau perusahaan.

d. Minimnya lapangan pekerjaan yang sesuai dengan tingkat pendidikan dan keterampilan yang dimiliki pencari kerja.

e. Minimnya modal usaha yang dimiliki pencari kerja/wirausaha.

f. Tingginya bunga KUR yang ditawarkan oleh lembaga jasa keuangan.

g. Kurangnya pengetahuan dan informasi yang detail mengenai syarat permohonan bantuan dana pada lembaga jasa keuangan.

h. Tingkat partisipasi masyarakat dalam mendukung terciptanya iklim perekonomian melalui perencanaan, pelaksanaan, dan pengawasan pembangunan infrastruktur ekonomi.

i. Terbatasnya keterampilan kerja yang dimiliki oleh pencari kerja (pengangguran) yang ada dikota palopo.

j. Tingginya gengsi yang dimiliki pencari kerja secara tidak langsung membatasi lapangan pekerjaan dan usaha.

\section{Identifikasi Faktor-Faktor Strategis Internal Ketenagakerjaan di Kota Palopo}

Berdasarkan dari hasil penelitian berupa survey ketenagakerjaan (2017) yang telah dilakukan sebelumnya maka yang menjadi peluang dan ancamanmengenai kondisi ketenagakerjaan di Kota Palopo adalah sebagai berikut :

1. Faktor-faktor yang menjadi peluang mengenai kondisi ketenagakerjaan di Kota Palopo: a. Tersedianya berbagai tawaran program magang dan pelatihan keterampilan oleh SKPD terkait.

b. Kemajuan teknologi yang sangat pesat dalam menyongsong era revolusi industri 4.0.

c. Ditandatanganinya kesepakatan perdagangan bebas antara Indonesia dengan pemerintah China dalam hubungannya dengan pertumbuhan ekonomidi Kota Palopo.

d. Investasi swasta dilingkungan Kota Palopo dalam upaya mendukung pembangunan dan peningkatan ekonomi.

e. Kerjasama dengan daerah-daerah seputar Kota Palopo dalam upaya peningkatan pertumbuhan ekonomi.

f. Berbagai program pemerintah pusat dalam upaya mendukung pembangunan dan peningkatan ekonomi di Kota Palopo.

g. Adanya sinergitas/kerjasama antara pemerintah dengan perguruan tinggi dalam menciptakan tenaga kerja dan wirausaha yang handal.

h. Adanya sinergitas/kerjasama antara pemerintah dengan industri perbankan dalam mendukung modal tenaga kerja dan wirausaha.

i. Adanya sinergitas/kerjasama antara pemerintah dengan LSM dan Tokoh Masyarakat dalam menciptakan iklim yang kondusif bagi tenaga kerja dan wirausaha.

2. Faktor-faktor yang menjadi ancaman mengenai kondisi ketenagakerjaan di Kota Palopo:

a. Tidak tersedianya sarana informasi berupa layanan teknologi yaitu website tentang lowongan pekerjaan baik dalam dan luar negeri.

b. Ketepatan sasaran dari beberapa program magang dan pelatihan keterampilan yang ditawarkan sesuai dengan kebutuhan pencari kerja dan pasar kerja saat ini.

c. Nepotisme merupakan salah satu faktor penghambat bagi pencari kerja untuk bisa diterima pada instansi atau perusahaan.

d. Nepotisme merupakan salah satu faktor penghambat bagi pencari kerja atau wirausaha untuk bisa memperoleh bantuan.

e. Mulai munculnya persaingan antara tenaga kerja lokal dan tenaga kerja asing yang mulai masuk ke Kota Palopo.

f. Minimnya pendampingan yang sifatnya kontinyu oleh perguruan tinggi kepada tenaga kerja dan usaha.

g. Minimnya pendapingan yang sifatnya kontinyu oleh industri lembaga perbankan kepada tenaga kerja dan wirausaha.

h. Perlindungan berupa PERDA terhadap tenaga kerja/wirausaha lokal akan dampak dari masuknya tenaga kerja asing. 


\section{Analisis Data}

\section{Uji Validitas dan Reliabilitas Variabel Penelitian}

Uji validitas dilakukan untuk setiap variabel laten yang dikontruksi oleh indikator-indikatornya masingmasing. Uji validitas digunakan untuk mengukur sah atau valid tidaknya suatu kuisioner (Imam Ghozali, 2006 : 49). Uji validitas dengan rumus The Product Moment Coeffisient Correlation yaitu dengan melihat $\mathrm{r}_{\text {hitung }}$ dan nilai significan/probabilitas masing-masing item pertanyaan dibandingkan dengan tingkat signifikan $5 \%$.

Berikut ini disajikan hasil olah data uji validitas dengan correlation product moment yaitu:

Tabel 4.2: Hasil Uji Validitas Indikator/Butir Pertanyaan Kekuatan, Kelemahan, Peluang, dan Ancaman.

\begin{tabular}{|c|c|c|c|c|c|}
\hline No & $\begin{array}{l}\text { No. Butir } \\
\text { Peranyaan }\end{array}$ & $\begin{array}{l}\text { Kode Item } \\
\text { Pertanyaan }\end{array}$ & r-hitung & Sign. & Keterangan \\
\hline 1 & Kekuatan & $\begin{array}{l}\text { KKT1 } \\
\text { KKT2 } \\
\text { KKT3 } \\
\text { KKT4 } \\
\text { KKT5 } \\
\text { KKT6 }\end{array}$ & $\begin{array}{l}0,847 \\
0,749 \\
0,831 \\
0,651 \\
0,843 \\
0,395\end{array}$ & $\begin{array}{l}0,000 \\
0,000 \\
0,000 \\
0,000 \\
0,000 \\
0,002 \\
\end{array}$ & $\begin{array}{l}\text { Valid } \\
\text { Valid } \\
\text { Valid } \\
\text { Valid } \\
\text { Valid } \\
\text { Valid }\end{array}$ \\
\hline 2 & Kelemahan & $\begin{array}{c}\text { KLM1 } \\
\text { KLM2 } \\
\text { KLM3 } \\
\text { KLM4 } \\
\text { KLM5 } \\
\text { KLM6 } \\
\text { KLM7 } \\
\text { KLM8 } \\
\text { KLM9 } \\
\text { KLM10 }\end{array}$ & $\begin{array}{c}-0,495 \\
0,462 \\
0,353 \\
0,668 \\
0,594 \\
0,526 \\
0,659 \\
0,420 \\
0,759 \\
0,748\end{array}$ & $\begin{array}{l}0,000 \\
0,000 \\
0,006 \\
0,000 \\
0,000 \\
0,000 \\
0,000 \\
0,000 \\
0,000 \\
0,000\end{array}$ & $\begin{array}{c}\text { Valid } \\
\text { Valid } \\
\text { Valid } \\
\text { Valid } \\
\text { Valid } \\
\text { Valid } \\
\text { Valid } \\
\text { Valid } \\
\text { Valid } \\
\text { Valid }\end{array}$ \\
\hline 3 & Peluang & $\begin{array}{l}\text { P1 } \\
\text { P2 } \\
\text { P3 } \\
\text { P4 } \\
\text { P5 } \\
\text { P6 } \\
\text { P7 } \\
\text { P8 } \\
\text { P9 }\end{array}$ & $\begin{array}{l}0,450 \\
0,490 \\
0,552 \\
0,670 \\
0,750 \\
0,772 \\
0,832 \\
0,725 \\
0,358\end{array}$ & $\begin{array}{l}0,000 \\
0,000 \\
0,000 \\
0,000 \\
0,000 \\
0,000 \\
0,000 \\
0,000 \\
0,005\end{array}$ & $\begin{array}{c}\text { Valid } \\
\text { Valid } \\
\text { Valid } \\
\text { Valid } \\
\text { Valid } \\
\text { Valid } \\
\text { Valid } \\
\text { Valid } \\
\text { Valid }\end{array}$ \\
\hline 4 & Ancaman & $\begin{array}{l}\text { A1 } \\
\text { A2 } \\
\text { A3 } \\
\text { A4 } \\
\text { A5 } \\
\text { A6 } \\
\text { A7 } \\
\text { A8 }\end{array}$ & $\begin{array}{l}0,485 \\
0,360 \\
0,453 \\
0,608 \\
0,625 \\
0,531 \\
0,803 \\
0,640\end{array}$ & $\begin{array}{l}0,000 \\
0,000 \\
0,000 \\
0,000 \\
0,000 \\
0,000 \\
0,000 \\
0,000\end{array}$ & $\begin{array}{l}\text { Valid } \\
\text { Valid } \\
\text { Valid } \\
\text { Valid } \\
\text { Valid } \\
\text { Valid } \\
\text { Valid } \\
\text { Valid }\end{array}$ \\
\hline
\end{tabular}

Sumber Data Primer diolah 2018

\section{Hasil Uji Reliabilitas}

Selain harus valid, instrumen juga harus reliabel (konsisten). Instrumen dikatakan reliabel apabila indikator-indikator tersebut memperoleh hasil-hasil yang konsisten. Suatu kuisioner dikatakan reliabel atau handal jika jawaban seseorang terhadap pernyataan adalah konsisten atau stabil. Untuk menguji reliabilitas instrumen pengukuran digunakan prosedur Cronbach's Alpha. Adapun hasil uji reliabilitas untuk masing-masing variabel yaitu:

Tabel 4.3: Hasil Uji Realibilitas Untuk Kekuatan, Kelemahan, Peluang, dan Ancaman. 


\begin{tabular}{|c|c|c|}
\hline Variabel & $\sqcup$-hit & Keterangan \\
\hline Kekuatan & $0, \overline{815}$ & \\
\hline Kelemahan & 0,611 & Reliabel \\
\hline Peluang & 0,805 & $\sqcup>0,60$ \\
\hline Ancaman & $\underline{0,703}$ & \\
\hline
\end{tabular}

Sumber Data Primerdiolah 2018

Dari hasil analisis uji reliabilitas pada tabel 6 di atas, maka dapat dikatakan bahwa data yang digunakan reliabel. Dengan demikian hasil pengujian validitas dan reliabiitas menyimpulkan bahwa seluruh butir pertanyaan berstatus valid untuk setiap variabel penelitian, dan reliabel untuk seluruh variabel.

\section{Menentukan Matrik IFAS(Internal Strategic Analysis Summary) dan EFAS (Eksternal Strategic Analysis Summary)}

Faktor-faktor strategis perusahaan yang didapat kemudian diformulasikan dalam bentuk tabel IFAS (Internal Strategic Analysis Summary) dan EFAS (Eksternal Strategic Analysis Summary) yang mana sebelumnya memformulasikan IFAS dan EFAS terlebih dahulu dilakukan pembobotan terhadap masing-masing faktor strategis.Berikut disajikan tabel pemberian nilai dan bobot serta pemberian pembobotan dan rating:

Tabel 4.4: Hasil IFAS (Internal Strategic Analysis Summary)

\begin{tabular}{|c|c|c|c|c|}
\hline Faktor-faktor Strategi Internal & Penilaian & Bobot & Rating & $\begin{array}{l}\text { Bobot } \\
x \\
\text { Rating }\end{array}$ \\
\hline \multicolumn{5}{|l|}{ Kekuatan } \\
\hline Posisi Geografis Kota Palopo Strategis & 5 & 0.078 & 5 & 0.391 \\
\hline $\begin{array}{l}\text { Ketersediaan infrastruktur sarana } \\
\text { pendidikan, perguruan tinggi dan } \\
\text { lembaga pelatihan }\end{array}$ & 5 & 0.078 & 4 & 0.313 \\
\hline $\begin{array}{l}\text { Ketersediaan lembaga jasa keuagan } \\
\text { dalam menjamin modal usaha }\end{array}$ & 4 & 0.063 & 4 & 0.250 \\
\hline $\begin{array}{l}\text { Ketersediaan infrastruktur dasar yaitu } \\
\text { sarana kesehatan, irigasi, infrastruktur } \\
\text { jalan }\end{array}$ & 4 & 0.063 & 4 & 0.250 \\
\hline $\begin{array}{l}\text { Ketersediaan sarana \& prasarana } \\
\text { perekonomian yaitu pasar dan } \\
\text { kawasan ekonomi lainnya }\end{array}$ & 5 & 0.078 & 4 & 0.313 \\
\hline $\begin{array}{l}\text { Ketersediaan lapangan pekerjaan } \\
\text { dalam menyerap tenaga kerja }\end{array}$ & 3 & 0.047 & 3 & 0.141 \\
\hline Total & & & & 1.656 \\
\hline \multicolumn{5}{|l|}{ Kelemahan } \\
\hline $\begin{array}{l}\text { Rendahnya Etos kerja, keuletan, dan } \\
\text { jiwa kewirausahaan masyarakat di } \\
\text { sektor perekonomian mikro dalam } \\
\text { upaya mendukung pertumbuhan makro } \\
\text { perekonomian }\end{array}$ & 4 & 0.063 & 1 & 0.063 \\
\hline $\begin{array}{l}\text { Tingginya persaingan antara pencari } \\
\text { kerja lokal dan dari luar Kota Palopo }\end{array}$ & 4 & 0.063 & 2 & 0.125 \\
\hline $\begin{array}{l}\text { Tingkat pendidikan/keterampilan yang } \\
\text { masih rendah }\end{array}$ & 5 & 0.078 & 2 & 0.156 \\
\hline $\begin{array}{l}\text { Minimnya lapangan pekerjaan yang } \\
\text { sesuai dengan tingkat pendidikan dan } \\
\text { keterampilan }\end{array}$ & 4 & 0.063 & 1 & 0.063 \\
\hline Minimnya modal usaha & 2 & 0.031 & 1 & 0.031 \\
\hline $\begin{array}{lccr}\begin{array}{l}\text { Tingginya } \\
\text { ditawarkan } \\
\text { keuangan }\end{array} & \begin{array}{c}\text { bungan } \\
\text { oleh }\end{array} & \begin{array}{c}\text { KUR } \\
\text { lembaga }\end{array} & \begin{array}{r}\text { yang } \\
\text { jasa }\end{array} \\
\end{array}$ & 4 & 0.063 & 2 & 0.125 \\
\hline $\begin{array}{l}\text { Kurangnya informasi mengenai syarat } \\
\text { permohonan bantuan dana pada } \\
\text { lembaga jasa keuangan }\end{array}$ & 4 & 0.063 & 3 & 0.188 \\
\hline $\begin{array}{lcc}\text { Rendahnya } & \text { tingkat } & \text { partisipasi } \\
\text { masyarakat } & \text { dalam mendukung } \\
\text { terciptanya iklim perekonomian }\end{array}$ & 3 & 0.047 & 3 & 0.141 \\
\hline $\begin{array}{l}\text { Terbatasnya keterampilan kerja yang } \\
\text { dimiliki pencari kerja }\end{array}$ & 3 & 0.047 & 2 & 0.094 \\
\hline 10. Tingginya gengsi & 5 & 0.078 & 1 & 0.078 \\
\hline Total & & & & 1.063 \\
\hline
\end{tabular}

\begin{tabular}{|c|c|c|c|c|}
\hline Total & 64 & 1.000 & & $\mathbf{2 . 7 1 9}$ \\
\hline
\end{tabular}

\section{Sumber Data Primer Diolah, 2018}

Tabel 4.5Hasil EFAS (External Strategic Analysis Summary)

\begin{tabular}{|c|c|c|c|c|}
\hline Faktor-faktor Strategi Eksternal & Penilaian & Bobot & Rating & $\begin{array}{l}\text { Bobot } \\
\quad x \\
\text { Rating }\end{array}$ \\
\hline \multicolumn{5}{|l|}{ Peluang } \\
\hline $\begin{array}{l}\text { Tersedianya berbagai tawaran program } \\
\text { magang dan pelatihan keterampilan } \\
\text { oleh SKPD }\end{array}$ & 5 & 0.068 & 3 & 0.205 \\
\hline Pemanfaatan pada kemajuan teknologi & 4 & 0.055 & 4 & 0.219 \\
\hline $\begin{array}{l}\text { Penandatanganan kesepakatan } \\
\text { perdagangan bebas antara Indonesia } \\
\text { dan Pemerintah China }\end{array}$ & 4 & 0.055 & 2 & 0.110 \\
\hline $\begin{array}{l}\text { Investasi swasta dilingkungan Kota } \\
\text { Palopo dalam upaya mendukung } \\
\text { pembangunan dan peningkatan } \\
\text { ekonomi }\end{array}$ & 4 & 0.055 & 2 & 0.110 \\
\hline $\begin{array}{l}\text { Adanya kerjasama dengan daerah- } \\
\text { daerah seputar Kota Palopo }\end{array}$ & 4 & 0.055 & 1 & 0.055 \\
\hline $\begin{array}{l}\text { Adanya berbagai program pemerintah } \\
\text { pusat }\end{array}$ & 4 & 0.055 & 4 & 0.219 \\
\hline $\begin{array}{l}\text { Adanya sinergitas/kerjasama antara } \\
\text { perguruan tinggi dengan pemerintah } \\
\text { dalam menghasilkan tenaga kerja dan } \\
\text { wirausaha yang handal }\end{array}$ & 5 & 0.068 & 2 & 0.137 \\
\hline $\begin{array}{l}\text { Adanya sinergitas/kerjasama antara } \\
\text { pemerintah dengan industri perbankan } \\
\text { dan industri lainnya dalam mendukung } \\
\text { modal usaha dan penyerapan tenaga } \\
\text { kerja }\end{array}$ & 5 & 0.068 & 2 & 0.137 \\
\hline $\begin{array}{l}\text { Adanya sinergitas/kerjasama antara } \\
\text { pemerintah dengan LSM dan Tokoh } \\
\text { Masayrakat dalam menciptakan iklim } \\
\text { perekonomian yang kondusif bagi } \\
\text { Tenaga kerja dan wirausaha }\end{array}$ & 4 & 0.055 & 2 & 0.110 \\
\hline Total & & & & 1.301 \\
\hline \multicolumn{5}{|l|}{ Ancaman } \\
\hline $\begin{array}{l}\text { Tidak tersedianya sarana informasi } \\
\text { berupa layanan teknologi seperti } \\
\text { website tentang info lowongan } \\
\text { pekerjaan }\end{array}$ & 5 & 0.068 & 2 & 0.137 \\
\hline $\begin{array}{l}\text { Ketepatan sasaran dari beberapa } \\
\text { program magang dan pelatihan } \\
\text { keterampilan yang ditawarkan }\end{array}$ & 3 & 0.041 & 2 & 0.082 \\
\hline $\begin{array}{l}\text { Nepotisme merupakan salah satu } \\
\text { faktor penghambat bagi pencari kerja } \\
\text { untuk bisa diterima pada instansi atau } \\
\text { perusahaan }\end{array}$ & 5 & 0.068 & 2 & 0.137 \\
\hline $\begin{array}{l}\text { Nepotisme merupakan salah satu } \\
\text { faktor penghambat bagi pencari kerja } \\
\text { atau wirausaha untuk bisa memperoleh } \\
\text { bantuan }\end{array}$ & 5 & 0.068 & 2 & 0.137 \\
\hline $\begin{array}{l}\text { Mulai munculnya persaingan antara } \\
\text { tenaga kerja lokal dan tenaga kerja } \\
\text { asing yang mulai masuk ke Kota } \\
\text { Palopo }\end{array}$ & 4 & 0.055 & 3 & 0.164 \\
\hline $\begin{array}{l}\text { Minimnya pendampingan yang } \\
\text { sifatnya kontinyu oleh perguruan } \\
\text { tinggi kepada tenaga kerja dan usaha }\end{array}$ & 4 & 0.055 & 1 & 0.055 \\
\hline $\begin{array}{l}\text { Minimnya pendapingan yang sifatnya } \\
\text { kontinyu oleh industri lembaga } \\
\text { perbankan kepada tenaga kerja dan } \\
\text { wirausaha }\end{array}$ & 4 & 0.055 & 1 & 0.055 \\
\hline $\begin{array}{l}\text { Perlindungan berupa PERDA terhadap } \\
\text { tenaga kerja/wirausaha lokal akan } \\
\text { dampak dari masuknya tenaga kerja } \\
\text { asing }\end{array}$ & 4 & 0.055 & 2 & 0.110 \\
\hline Total & & & & 0.877 \\
\hline Total & 73 & 1.000 & & 2.178 \\
\hline
\end{tabular}

Sumber Data Primer Diolah, 2018

\section{Menentukan Posisi Kuadran}

Berdasarkan Klasifikasi IFAS pada Tabel 4.3 dan EFAS pada Tabel 4.4 diketahui bahwa skor total untuk faktor-faktor strategis internal adalah 2,783, sedangkan untuk skor total faktor strategis eksternal adalah 2,825. Untuk mengetahui gambaran strategis perusahaan 
berdasarkan formulasi IFAS dan EFAS pada tabel 4.6 dan tabel 4.7 selanjutnya diperhitungkan dengan matrik Internal Eksternal (IE Matrik) pada gambar berikut:

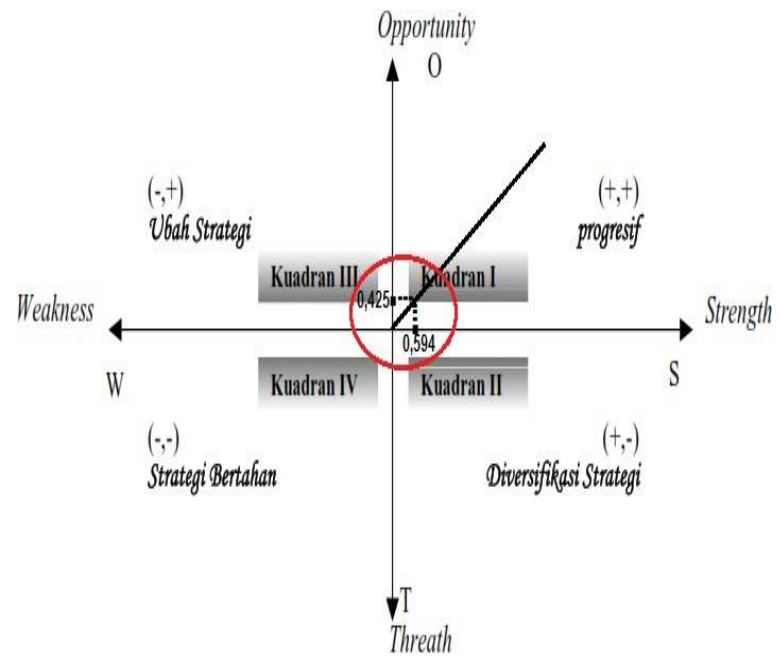

\section{Gambar 4.2 Posisi Kuadran dari Matriks SWOT}

Berdasarkan dari hasil perhitungan Matriks IFAS \& EFAS diperoleh posisi Kuadran dari Matriks SWOT yaitu:

Pada Posisi Kuadran I

Kekuatan - Kelemahan $=1,656-1,063=0,594$ Kekuatan - Kelemahan $=1,301-0,877=0,425$. Posisi ini menandakan sebuah organisasi yang kuat dan berpeluang, Rekomendasi strategi yang diberikan adalah Progresif, artinya organisasi dalam kondisi prima dan mantap sehingga sangat dimungkinkan untuk terus melakukan ekspansi, memperbesar pertumbuhan dan meraih kemajuan secara maksimal.

\section{Menentukan Altrenatif Strategi}

Berdasarkan variabel Internal dan Eksternal pada IFAS dan EFAS pada Tabel 4.4 dan 4.5 selanjutnya dicari alternatif strategi melaui formulasi matrik analisis SWOT. Berikut adalah formulasi matrik SWOT:

Berdasarkan dari hasil penelitian yang telah dilakukan melalui pendekatan analisis SWOT lahir beberapa strategi yaitu:

\section{Strategi S-O}

a. Pemerintah melalui balitbangda harus memanfaatkan perguruan tinggi yang ada di Kota Palopo dengan membentuk tim yang berisikan pakar/ahli dari masing-masing perguruan tinggi yang nantinya bertugas mendampingi dan merumuskan indikator penilaian kemandirian dari output pelatihan (SDM tenaga kerja/wirausaha).

b. Dengan tersedianya sarana dan prasarana perekonomian yang dimiliki Kota Palopo, pemerintah dapat memanfaatkan etos kerja, keuletan, dan jiwa kewirausahaan masyarakat di sektor perekonomian mikro untuk semakin memperkuat perekonomian melalui kelompok usaha industri kecil, UMKM, dan koperasi, dalam rangka mempersiapkan diri menghadapi persaingan bebas.

c. Pemerintah melalui balitbangda harus membuat inkubator yang bersinergi dengan inkubator perguruan tinggi yang ada di Kota Palopo yang berisikan hasil riset dan pengabdian, yang nantinya bisa dijadikan sebagai pijakan awal bagi balitbangda dalam menyusun rencana kegiatan pengembangan penelitian dan pengabdian

2. Strategi S-T

a. Memanfaatkan perkembangan teknologi yaitu dengan menambahkan fitur pada website Kota Palopo tentang informasi ketenagakerjaan seperti info tentang kegiatan pelatihan, info tentang syarat permohonan bantuan dana, info tentang lowongan pekerjaan yang tentunya harus bersifat uptodate

b. Pemerintah Kota Palopo harus membuat PERDA perlindungan terhadap tenaga kerja lokal untuk membatasi masuknya tenaga kerja asing di Kota Palopo.

\section{Strategi W-O}

a. Meningkatkan etos kerja, keuletan, dan jiwa kewirausahaan masyarakat melalui kegiatan pelatihan-pelatihan dengan memanfaatkan program program bantuan dari pemerintah daerah, provinsi dan pusat yang tentunya melalui proses pendampingan dari perguran tinggi.

b. Pemerintah harus fokus kepada pengembangan jiwa kewirausahaan yang dimiliki oleh masyarakat untuk membangun industri kecil dan menengah dalam rangka persaingan dengan berbagai produk China yang sudah marak masuk ke pasar Indonesia.

c. Pemerintah harus memanfaatkan investasi swasta dan kerjasama dengan daerah-daerah seputar Kota Palopo dalam membuka lapangan pekerjaan.

d. Pemrintah, LSM, dan Tokoh Masyarakat harus bersinergi dalam memberikan pemahaman kepada masyarakat untuk ikut serta berpartisipasi dalam menciptakan iklim perekonomian di Kota Palopo.

e. Pemerintah Kota Palopo memberikan bantuan dan penguatan permodalan bagi tenaga kerja dan industri kreatif (seperti dana bergulir, pembiayaan bagi tenaga kerja yang terampil yang siap di pekerjakan didalam dan diluar negeri.

4. Strategi W-T

a. Pemerintah dalam membuat program pelatihan hendaknya terus melakukan kolaborasi dengan perguruan tinggi melalui pendampingan dengan tujuan bahwa perguruan tinggi mampu mentransfer iptek dan keterampilan yang sifatnya uptodate.

b. Pemerintah harus memberikan komitmen dukungan kekuatan politiknya secara proporsional yaitu berupa kebijakan-kebijakan yang berkaitan dengan people, industri, institusi, intermediasi dan sumber daya dan teknologi sebagai upaya dalam menciptakan stimulus dalam terciptanya iklim 
usaha yang kondusif bagi lahirnya industri kreatif di Kota Palopo

Dengan demikian maka dihasilkan dua belas rumusan strategi perspektif Quadruple Helix Model. Dimana dari kedua belas strategi tersebut apabila digambarkan maka bentuk kolaborasinya adalah sebagai berikut:

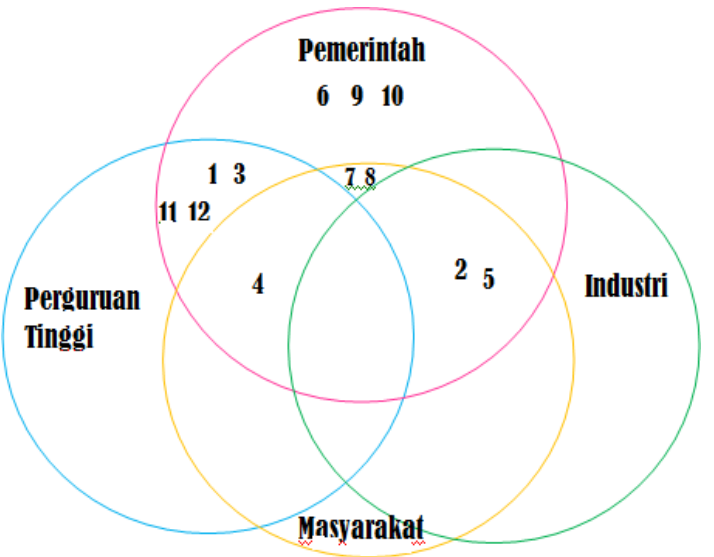

\section{Gambar 4.3 Kolaborasi Strategi (Quadruple Helix Model)}

Dengan demikian yang menjadi rekomendasi utama dari 12 strategi yang telah dihasilkan yaitu hendaknya pemerintah melalui Balitbangda membuat inkubator kewirausahaan siapa mau kerja apa.

\section{Menentukan Pilihan Strategi}

Berdasarkan pada hasil analisis matriks IFAS dan EFAS dimana diperoleh posisi yaitu pada kuadran pertama atau pada posis progresif, artinya organisasi dalam kondisi prima dan mantap sehingga sangat dimungkinkan untuk terus melakukan ekspansi, memperbesar pertumbuhan dan meraih kemajuan secara maksimal dan dari dua belas poin rumusan strataegi yang direkomendasikan yang dianggap relevan untuk dipertimbangkan dilaksanakan pada tahun 2019 yaitu rumusan strategi SO (Strength \& Opportunity) yaitu pemerintah melalui balitbangda perlu untuk membuat inkubator kewirausahaan yang berbasis sinergitas antara pemerintah perguruan tinggi, industri, dan masyarakat.

\section{KESIMPULAN}

\section{Hasil Penelitian}

Berdasarkan dari hasil riset dengan menggunakan analisis SWOT maka dihasilkan rancangan strategi dan model inkubator kewirausahaan Pemerintah Kota Palopo. Berdasarkan rumusan strategi SO (Strength \& Opportunity) dihasilkan tiga rekomendasi strategi, untuk Strategi WO (Weakness \& Opportunity) menghasilkan lima rekomendasi strategi, selanjutnya untuk Strategi ST (Strength \& Threat) menghasilkan dua rekomendasi strategi, kemudian untuk Strategi WT (Weakness \& Threat) menghasilkan dua strategi.

\section{Rekomendasi}

Berdasarkan dari hasil rumusan strategi yang telah dihasilkan maka yang menjadi rekomendasi untuk dilaksanakan yaitu:

1. Pemerintah

a. Pemerintah melalui balitbangda harus memanfaatkan perguruan tinggi yang ada di Kota Palopo dengan membentuk tim yang berisikan pakar/ahli dari masing-masing perguruan tinggi yang nantinya bertugas mendampingi dan merumuskan indikator penilaian kemandirian dari output pelatihan (SDM tenaga kerja/wirausaha).

b. Pemerintah melalui balitbangda harus membuat inkubator yang bersinergi dengan inkubator perguruan tinggi yang ada di Kota Palopo yang berisikan hasil riset dan pengabdian, yang nantinya bisa dijadikan sebagai pijakan awal bagi balitbangda dalam menyusun rencana kegiatan pengembangan penelitian dan pengabdian.

c. Meningkatkan etos kerja, keuletan, dan jiwa kewirausahaan masyarakat melalui kegiatan pelatihan-pelatihan yang bersifat sustainability (berkelanjutan) dengan memanfaatkan program program bantuan dari pemerintah daerah, provinsi dan pusat yang tentunya melalui proses pendampingan dari perguran tinggi.

d. Pemerintah Kota Palopo memberikan bantuan dan penguatan permodalan bagi tenaga kerja dan industri kreatif (seperti dana bergulir, pembiayaan bagi tenaga kerja yang terampil yang siap di pekerjakan didalam dan diluar negeri.

e. Memanfaatkan perkembangan teknologi yaitu dengan menambahkan fitur pada website Kota Palopo tentang informasi ketenagakerjaan seperti info tentang kegiatan pelatihan, info tentang syarat permohonan bantuan dana, info tentang lowongan pekerjaan yang tentunya harus bersifat uptodate.

f. Pemerintah harus memberikan komitmen dukungan kekuatan politiknya melalui PERDA secara proporsional yaitu berupa kebijakankebijakan yang berkaitan dengan masyarakat, industri, institusi, intermediasi dan sumber daya dan teknologi sebagai upaya dalam menciptakan stimulus dalam terciptanya iklim usaha yang kondusif bagi lahirnya industri kreatif di Kota Palopo

2. Perguruan Tinggi

a. Perguruan tinggi dalam setiap tahunnya melalui lembaga penelitian dan pengabdian membuat program riset dan pengabdian baik dalam bentuk rekayasa produk, pelatihan keterampilan yang disinergikan dengan kebutuhan Pemerintah melalui pendampingan dengan tujuan bahwa perguruan tinggi mampu mentransfer iptek dan keterampilan yang sifatnya uptodate.

b. Perguruan tinggi menyediakan pendampingan berupa pelatihan keterampilan bahasa asing contohnya bahasa inggris, dan bahasa mandarin. 
3. Industri/Bisnis

a. Pihak industri bekerjasama dengan perguruan tinggi untuk memberikan peluang kepada lulusannya untuk bisa magang secara langsung.

b. Industri bisa membantu individu atau kelompok masyrakat melalui dana CSR (Corporate Social Responsibility).

4. Masyarakat

a. Masyarakat hendaknya mengaktifkan kelompok kelompok usaha yang ada di desa maupun kelurahan misalnya melalui BUMDES, Kelompk Tani, Kelompok Nelayan dan Ibu-Ibu PKK dengan memanfaatkan dana desa sehingga dapat membantu perguruan tinggi untuk membuat usulan pengembangan program kegiatan riset dan pengabdian.

b. Kelompok masyarakat yang terkategori produktif dapat berperan sebagai percontohan dalam memotivasi individu dalam lingkungannya untuk terlibat aktif dalam kegiatan yang dilakukan oleh kelompok tersebut.

\section{DAFTAR PUSTAKA}

Badan Pusat Statistik Kota Palopo. 2017. Dalam angka 2017. Palopo

Badan Pusat Statistik.Analisis Sensus Ekonomi 2006 Mengenai Ketenagakerjaan Provinsi Sulawesi Selatan (Hasil Sensus Sampel 2007). (Makassar: BPS Sulsel, 2007). Hal. 52

Muhdar H.M. (2015). Potret Ketenagakerjaan, Pengangguran dan Kemiskinan di Indonesia: Masalah dan Solusi. Al-Buhuts, 11(1), 42-66.

Padil dan Titi., A. 2018. Paradigma Baru Pengabdian Kepada Masyarakat yang Berkelanjutan. Jurnal Pengabdian Masyarakat. Vol.1 No.2

Peraturan Presiden No.32 Tahun 2011 Tentang Masterplan Percepatan dan Perluasan Pembangunan Ekonomi Indonesia 2011-2025

Rangkuti, Freddy. 1997. Analisis SWOT Teknik Membedah Kasus Bisnis. Jakarta: Gramedia Pustaka Utama

Recana Pembangunan Jangka Menengah Daerah Kota Palopo 2013-2018 Badan Perencanaan Pembangunan Daerah (2013)

Sugiyono, 2009. Metode Penelitian Kuantitatif, Kualitatif dan R\&D. Bandung : Alfabeta.

Yawson R. M., 2009, The Ecological System of Innovation: A New Architectural Framework for a Functional Evidence-Based Platform for Science and Innovation Policy, The Future of Innovation Proceedings of the XXIV ISPIM 2009 Conference, Vienna,Austria, June 21-24, 2009 